\title{
Creating an Islamic cultural sphere: contested notions of art, leisure and entertainment. An Introduction
}

\author{
Karin van Nieuwkerk
}

Published online: 15 November 2008

(C) The Author(s) 2008. This article is published with open access at Springerlink.com

Keywords Art · Entertainment · Cultural sphere · Public sphere · Islam

The public sphere in the Middle East and elsewhere is changing rapidly due to the global availability of new technologies of mass media. As a result of the growing influence of Islamist and pietistic movements in the Muslim world and in Muslim communities in the West, an increasing Islamization or 'pietization' (Turner 2008) of the public sphere is discernable. Also with regard to the cultural sphere attempts are made to bring art, leisure and entertainment in accordance with religious commitments. Pious sensibilities seem to be a moving but not necessarily dominating force in the creation of new forms of artistic expressions and leisure activities. Secularism, in particular, and 'the grand project of nationalist progress' (Schielke, this issue) are still very influential in the field of art. In much of the Arab world, mass culture is still one of the few remaining bastions of secularism (Salamandra, this issue). Secularist regimes perceive art and entertainment as important strongholds that are in need of defence. For that reason religious notions of art, leisure and entertainment are highly contested. Journalists, Islamists, artists and art consumers redefine the relationship between religion, art and leisure activities. The debates are raging within and between the secularists and the Islamist groups and profoundly discuss the place of religion in the public sphere.

This special issue is the outcome of a panel organised on this topic at the MESA conference in 2007. We will highlight several examples of the ways piety is creatively merged with art and sketch the development towards a pious cultural sphere. Yet equally important is how these projects are debated, consumed and contested by diverse actors inside and outside the piety movement.

K. van Nieuwkerk $(\square)$

Radboud University Nijmegen, P.O. Box 9102, 6500 Nijmegen, The Netherlands

e-mail: k.v.nieuwkerk@let.ru.nl 


\section{Art and popular culture: between Islamism and Secularism}

Popular culture, entertainment and performing arts are specific targets for the cultural politics of competing groups because they are very influential in people's daily lives and lifestyles. Art and popular culture are vital in identity construction of individuals and communities. Art is a boundary marker between different cultures, subcultures and ethnicities. It can therefore be expected that in art and expressive culture different imaginations of identities, ideals and belongings compete.

In Dramas of Nationhood, Abu Lughod (2005) shows that television is a key institution for the production of national culture in Egypt. It produces nations, national feelings and shapes national imaginaries (2005: 8). The discourse of national development and "development realism" not only dominated Egypt but most media of the Third World (2005: 108) The nationalist and developmentalist discourses of the state lost its hegemony in the 1990s. Globalisation and Islamism became serious competitors. State-owned media could still use media to promote its nationalist vision by presenting Islamists as violent, ignorant and backward extremists. In this way, media remained tools for strengthening Arab national identity (Khatib 2006). Egyptian actresses, for instance, who tried to act veiled were charged with being 'fundamentalists.' They were also accused of being paid for veiling by Saudi Arabia who allegedly intended to spread a Bedouin, desert vision of Islam by way of the 'repentant' artists. They were denied access on the Egyptian state television (Van Nieuwkerk, this issue). Through censorship the state is still highly influential in the direction art and entertainment can develop. Yet with new media technology and satellite television the state is no longer able to completely control the mediascape.

Secularists have used art for their national pedagogical projects or to combat 'extremism.' Islamists alternatively, generally have a strained relationship with art and entertainment. As Bayat argues, Islamism and fun or entertainment seem to be an unlikely pair (Bayat 2007). Otterbeck illustrates the hostility puritan Islamists can express towards fun in the form of music (Otterbeck, this issue). During the 1950s, the committee for the Advancement of Virtue and Elimination of Vice in Saudi Arabia banned music and singing for its connection with immoral behaviour and Sufism. In Afghanistan the Taliban regime (1996-2001) forbade common diversions such as watching television, dancing, listening to music and flying kites (Bayat 2007: 446). The 'anti-fun-damentalism' is however not restricted to Islamists and Islam but extends to most religions or, as Bayat argues, to all rigid one-dimensional doctrinal ideologies, whether Marxists or Islamists (Bayat 2007: 457).

Yet this does not deny the fact that the relationship between art, leisure and entertainment on the one hand and Islamic authorities and their rulings on the other is charged. The emotional affect of music and singing, the stirring effect of musical instruments, the "corrupting" influence of dancing and movies, and the 'illegitimate' nature of human images are sensitive matters for religious scholars. There is a wide range of opinions among religious scholars on the permissibility of singing, dancing and music. Internet sites and debate forums are full of discussions about the issue. Otterbeck discusses in detail the different ideas of hardliners, moderates and liberals regarding music (Otterbeck, this issue). Hardliners, using new media and formulating their opinions in a disproportionate authoritative way, claim that music 
destroys public morals or is an evil created by Satan. The liberal position is presented by the Lebanese scholar al-Mardini (Otterbeck, this issue; Levine, this issue). He avoids the categories of halal and haram and rejects all kinds of censorship. He argues for tolerance and coexistence with popular music. Moderates such as al-Qaradawi and the lay preacher Amr Khaled do not consider music in itself haram. Rather it is the content of lyrics and the sexual suggestiveness of certain music that makes it haram (Otterbeck, this issue). At present, the views of several religious scholars seem to be on the move towards a more relaxed and accepting position of art and entertainment within the limits of religious sensibilities. The new Islamist trend in Egypt, or the wasatiyya movement, embraces art and argues that an Islamic community without art is unimaginable. The God-given talents should be used to express core religious values. They neither agree with the total condemnation of art nor with the secularists' call for absolute freedom (Baker 2003). 'Respectful' art and entertainment can promote Muslim lifestyles. Amr Khaled, for instance, calls upon artists to return to art. They should help the Islamic revival and create an Islamic alternative and ambience. He tries to promote 'art with a mission', 'al-fann al-hadif. ${ }^{1}$

Islamists and secularists thus compete for the art producers' and consumers' tastes and preferences. Both Salamandra (this issue) and Becker (forthcoming issue) show how artists are balancing opposing trends and traditions. Syrian television makers try to balance secularism and the need for authenticity which is increasingly connected with revivalist Islam. They do so by incorporating historic Islamic imagery in their productions while avoiding reference to Islam's contemporary social and political relevance. 'Islam is folklorized as bygone custom and tradition, or aestheticized as costume history' (Salamandra, this issue), a strategy also known in Egypt. Several veiled actresses stepped down for lack of any suitable roles as a veiled actress. On Egyptian TV they could only act in religious and historical plays glorifying Islam's distant past and were denied roles in the famous musalsalat, drama series, which would attest to Islam's present importance (Van Nieuwkerk, personal interviews).

The Moroccan case is slightly different as the king has imposed a vision of nationalism that is largely based on the Arab-Islamic heritage, with the monarch - a descendent of the Prophet Muhammed - as the leader of the faithful (Becker, forthcoming issue). Artistic expression is not allowed to threaten the king, Islam and the nationalist view of Morocco as an Arab-Islamic nation. Yet, since the recent democratic trend in Morocco, a new generation of artists is beginning to test notions of Islam, the monarch and the rights of women and ethnic groups. These artists however show self-censorship and create art that falls within the public discourse allowed by the new king. The public vision of Islam is one of peace and moderation and emphasises Sufi spirituality. Sufi elements are freely used by artists but Berber or Amazigh identity, perceived as threatening the Moroccan Arab identity, is viewed as a politically charged act of aggression against the government. Moroccan visual artists, for fear of censorship and surveillance, show self-restraint. They accordingly present Amazigh heritage as folkloric symbols. A similar strategy is thus adopted as in Syria and Egypt: the elements within the artistic expression that should be

\footnotetext{
${ }^{1}$ See for instance his project on internet. 'Markaz al-fann al-hadif.' Available online http://forum. amrkhaled.net/showthread.php?t=1356. (accessed 16th of October 2007)
} 
depoliticised are folklorised and relegated to the safe remoteness of the past, in this case the Amazigh cultural expression.

The trend of grassroots Egyptian Sufi dance music called 'mulid,' shows an interesting twist as well. It draws musically and lyrically on the Sufi tradition of inshad (a form of spiritual, ritual-focused singing), yet combines this with a youthful, boisterous dance style (Peterson, this issue). The tolerance towards this boisterous and cheeky style of spirituality is among others related to the fact that in Egypt the Sufi milieu of saint's days celebrations are undervalued as quaint and backward. Making fun of and folklorising Sufi spirituality and piety is not considered blasphemous. As long as the mulid dance keeps clear of red lines such as formal religious teachings and the authority of the state, it is considered a matter of bad taste rather that bad morals.

The secularist and Islamist projects towards cultural life are thus often understood in a contrastive and competing light. Yet, the revivalist and nationalist projects regarding art and entertainment converge in their claim that artistic expression and diversion should have a purpose. Al-fann al-hadif, art with a mission, can serve nationalist and Islamist purposes. In both cases the underlying idea is that art should have a mission. The Islamist ideas mainly differ in that their goal of art and entertainment is moral improvement and the pietization of the believers' lifestyle (Schielke, this issue).

We can thus differentiate three different trends in the present scene of popular culture with regard to religion. Besides the marginalisation and demonisation of Islam as well as the de-politisation and folkorisation of Islam in art productions, we have outlined above, there is emerging a third tendency: that is, a tendency towards the pietization of art.

\section{Pious art and globalisation}

Not only popular culture is very influential in the everyday life of individuals. As Turner (2008) argues, piety movements generally tend to have a radical impact on the everyday life of their devotees as well. They encourage the believers to transform their dispositions and tastes, or habitus. 'Piety is about the construction of definite and distinctive life styles of new religious tastes and preferences' (Turner 2008: 2). The piety movement took many forms: veiling, building of mosques, foundation of Islamic organizations, Islamic banking, Islamic charity, growing attendance of sermons and religious education as well as availability of religious products (Starrett 1995; Mahmood 2005; Hirschkind 2006). It should accordingly be no wonder that the pious habitus also extends to the field of art and entertainment.

At present, many religious art productions are spreading throughout the Middle East and among Muslim communities in Europe and the United States. The spread of Islamic pop stars such as convert Yusif Islam - formerly known as Cat Stevens who after a long silence and absence from the musical scene returned with religious pop, is admired in the Middle East as well as among Muslim communities in the West. The recent pop star Sami Yusif produced one of the first religious video clips. The video clip with its dominant image of music, singing and dancing - and thus long considered by religious fans as vulgar and akin to 'porn' - has regained 
respectability. Brother Dash enjoys great popularity in the USA and beyond for his Islamic poet performances. Stand up comedy, theatre and video produced by artists who identify themselves as Muslims emerge all over Europe. In her first show after 9/11, the Muslim female stand up comedian Shazia Mirza started as follows: 'Hello, my name's Shazia Mirza, at least that's what it says on my pilot licence.' Like the comedy troupe 'Allah Made Me Funny' she clearly identifies as a Muslim. Shazia, for instance, does not joke about sex. ${ }^{2}$ The show 'Allah Made Me Funny' was considered halal by the Great Ayatollah of Iraq, Sistani, who issued a fatwa in response to the questions of the Shi'a community of Vancouver (Hussein 2007: 2432). No alcohol or pork is served and the show is short as not to interfere with the evening prayer. ${ }^{3}$ In both shows the politicised climate around Islam and terrorisms are uneasy topics of laughter.

The religious 'nasheed' bands singing religious songs are nowadays a common sight at weddings in Egypt. An increasing number of middle and upper-middle class families turn to this religious alternative to weddings featuring belly dancers and 'vulgar' entertainment. ${ }^{4}$ Muslim heavy metal and hip hop fans and artists have created a lively underground in Egypt, Pakistan, Morocco and Lebanon (Levine, this issue). Islamic historical productions are a known genre on the screen but presently Islamic soaps series with veiled actresses are broadcasted on satellite TV. Several 'repentant' actresses who retired several years ago suddenly returned en masse in Ramadan 2006 to act in religiously inspired social soaps. Egypt has a 'halal song' movement, that is, cassettes are produced in which popular songs are reworked and wordings considered unfit are replaced by proper ones. In addition, the 'clean cinema,' al-sinima al-nidifa, is popular among 'family-oriented' cinema lovers. Because there are no bed scenes, kissing or other shameful images it is suitable for the family to visit these films together.

Artists presently have new spaces for the creation of Islamic art and entertainment due to greater access to privately-owned satellite channels and new media. These developments also provide food for thought about globalisation. Globalisation does not only pertain to Western - mostly perceived as secular — influences on art and entertainment - heavy metal, hip hop, pop, soaps — in the region but also to Islamic genres going global. Both Brother Dash and Allah Made Me Funny toured Egypt and were well-received. Sami Yusuf, a British born Azerbaijani singer, has wide audiences in the West and the whole Muslim world as well. He was also

\footnotetext{
${ }^{2}$ See interview with her in The Guardian August 21, 2003 available online at http://arts.guardian.co.uk/ features/story/0,,1026348,00.html (accessed 28th of April 2008) and in San Francisco Chronicle May 14, 2003 available online at: http://www.sfgate.com/cgi-bin/article.cgi?f=/c/a/2003/05/14/DD306495.DTL (accessed 28th of April 2008)

${ }^{3}$ Radio interview by Jennifer Ludden, available online at http://www.npr.org/templates/story/story.php? storyId=4799868 (accessed 16th of October 2007)

${ }^{4}$ Islamic weddings started in the mid 1990s, mainly among students performing at weddings of their colleagues. At present it is a trend that has become fashionable among middle and upper-middle class families. The number of weddings celebrated in this fashion is small in comparison to secular weddings but it is a growing market. A leader of a religious band I interviewed in 2006 told me that whereas in 1995 he had 30 or 40 weddings a year, in 2005 he had 150 . Also the number of bands increased considerably to about 100 to 150 bands at present. He found out that in 2004 there were 500.000 weddings registered and calculated that $2 \%$ are celebrated as Islamic weddings (basing this figure on 100 bands performing at 100 Islamic weddings, which is on the conservative side).
} 
promoted by Amr Khaled in the latter's efforts to produce counter-culture music (Otterbeck, this issue). Not only Western music and art but also Islamic artistic productions go global. The same holds true for the financial structure of the entertainment industries. Not only American dollars but also petrodollars go global and influence the mediascape.

Censorship and funding are important factors and no longer the prerogative of central governments. As Salamandra and Van Nieuwkerk (this issue) discuss, the influence of censorship and money from the Gulf ruling elites is extensive. Most TV makers in Syria, for instance, must compete for funding and have to please the conservative censors from the Gulf Cooperation Council states. In Egypt as well, the Gulf States are the main customers of drama productions and can enforce their censorship regulations. And with the petrodollars, Islamic morality and prudishness moved in (Shafik 2001).

\section{Al-saha al-islamiyya or the Islamization of the public sphere?}

Phenomena like 'the clean cinema,' 'Islamic tourism,' 'Islamic stand up comedy' and 'Islamic heavy metal' attest to the growing influence of Islamic sensibilities in the public sphere. Together with nasheed groups, Islamic weddings, and 'green pop' they are interesting examples of a developing Islamic cultural sphere and the creation of Islamic aesthetics. Instead of banishing expressive art, Muslim performers create a saha islamiyya, a 'Muslim cultural sphere' (Harb 2006). In line with the piety movement, piety also plays an important role in the 'cultural public sphere' or 'cultural sphere', that is in the 'theatre of deliberation' that is concerned with culture and art.

The public sphere as defined by Habermas is based on the idea of a religiously neutral or secular rationality. Contrary to this notion, Salvatore and Eickelman (2004) have argued that there is no single form of public sphere for all contexts and times. The development, shape and the normative base of the public sphere is historically and culturally embedded. It is likely that the Habermasian notion is Eurocentric, that is, his ideas are insightful for understanding the development of the public sphere in Europe and the United States, but not necessarily in the Middle East. In the Muslim majority world, the role of religion in social and community life changed and developed but never receded. Many Muslims share conceptions about the common good which are (partly) defined in Islamic terms.

As Fraser (1990) has argued we should conceptualise the public sphere - or the cultural sphere in this case - as consisting of a multiplicity of publics. There are alternative publics and also members of subordinate social groups invent and circulate counter discourses and practices. The fact that there are multiple but unequal publics participating in the discursive arena means that we need to analyse the forms of contest and interaction of different publics and to identify the mechanism that makes some of them subordinate or hegemonic. Also in the debates on the emergent Muslim cultural sphere, attention is drawn to new and alternative kinds of publics - and not just the elite - that at present claim the right to speak in the religious and political arenas. Eickelman and Anderson (1999) have argued that in the emergent public sphere - made possible by the new media - there is a 
possibility for new publics and new voices to express new ideas. The heated debates between secularists, different brands of Islamists and conservatives concerning art, and pious art in particular, are an interesting case of competing publics. Yet whether the pious voice forms a new 'counterpublic' is a matter for further investigation.

Several contributions in this special issue point to the difficulty of labelling publics in sharply defined contrastive ways. The authors challenge established dichotomies that separate religious from supposedly secular spheres of life and the tendency to divide actors and publics along these lines. Publics overlap in several ways at various levels. Van Nieuwkerk (this issue) shows how on the discursive level different actors in the debate on "repentant" artists in Egypt are lumped together and hardly form a kind of counterpublic. Secularists are dependent and entangled with the regime but the same holds true for several fractions of the Islamic revival movement. In this light, Hirschkind's notion of counterpublic is interesting to investigate (2006). He conceptualises counterpublic not in terms of an autonomous oppositional movement that uses a rational form of reasoning. He situates the contestory character of the revivalist movement in the sensorium underlying the discursive practices it uses and in the separate moral space it crafts through training religious sensibilities and affects.

Levine (this issue) shows how in the globalised Muslim public spheres, ultraconservative Muslims and ultrasecular metalheads have more in common than they would like to admit. He analyses heavy metal and hip hop as religious phenomenon and argues that extreme metal and extreme Islam can be seen as opposing responses to similar experiences of oppression by their governments. The 'Elastic Sheikh' he met had no problem in comparing heavy metal — which he personally dislikes — with beating the chest and chanting loudly during prayers.

A similar elasticity cannot only be witnessed among ideologues and artists but also among fans and consumers. Schielke (this volume) analyses the escapist approach to fun and entertainments cultivated by many young people in contemporary rural Egypt. Monotony and unfulfilled aspirations for a better and more exciting life form a daily-lived experience and a discourse on life. Yet this does not lead to a choice between secular entertainment or Islam or even Islamic entertainments for that matter. Schielke concludes that the young people's attitudes neither fit the secularist tradition of arts and entertainment nor their revivalist contestations and reinterpretations. People are more ambivalent: 'finding life pointless at times, looking for new horizons at times, and trusting in God at times.'

Another interesting example of the 'neither nor' ambivalent elastic attitudes at the ground is provided in Peterson's contribution (this issue). She describes the current of "mulid dance", named after festivals held in the honour of saints, which exhibits the mixing of spiritual motifs with fun-driven youth music. The growing popularity of this music trend suggests a wide degree of tolerance for tongue-in-cheek fun making over and in spiritual contexts. It illustrates the ways in which notions of piety are mixed with street-smart dance rhythms and appropriated by youth in Egypt today.

This special issue thus intends to bring together case studies that highlight the emergence of a pious cultural sphere. The contributions analyse the debates and the reception of the recent trend in art and entertainment, inside and outside the piety movement. It focuses on the driving forces behind the development toward pious art 
such as new media, globalisation and the tensions between the secular nationalist project and the Islamic revival movement. Yet it also tries to deconstruct the dichotomous view on the religious versus the secular and show the ambiguities and elasticity in people's everyday patterns of consumption and production of popular culture.

Open Access This article is distributed under the terms of the Creative Commons Attribution Noncommercial License which permits any noncommercial use, distribution, and reproduction in any medium, provided the original author(s) and source are credited.

\section{References}

Abu Lughod, L. (2005). Dramas of nationhood. The politics of television in Egypt. Cairo: The American University in Cairo Press.

Bayat, A. (2007). Islamism and the politics of fun. Public Culture, 19(3), 433-460.

Baker, R. W. (2003). Islam without fear. Egypt and the new Islamists. Cambridge: Harvard University Press.

Eickelman, D. F., \& Anderson, J. W. (1999). Redefining Muslim publics. In D. F. Eickelman, \& J. W. Anderson (Eds.), New media in the Muslim world. The emerging public sphere (pp. 1-19). Bloomington: Indiana University Press.

Fraser, N. (1990). Rethinking the public sphere: a contribution to the critique of actually existing democracy. Social Text, 2526, 56-80.

Harb, M. (2006). Pious entertainment. Al-Saha traditional village. ISIM Review, 17, 10-12.

Hirschkind, C. (2006). The Ethical soundscape. New York: Columbia University Press.

Hussein, J. (2007). Allah made me funny. Emel Magazine, December 2007, 24-32

Khatib, L. (2006). Nationalism and otherness. The representation of Islamic fundamentalism in Egyptian cinema. European Journal of Cultural Studies, 9(1), 63-80.

Mahmood, S. (2005). Politics of piety. The Islamic revival and the feminist subject. Princeton: Princeton University Press.

Salvatore, A., \& Eickelman, D. F. (2004). Preface. In A. Salvatore, \& D.F. Eickelman (Eds.), Public Islam and the common good (pp. xi-xxiii). Leiden: Brill.

Shafik, V. (2001). Prostitute for a good reason: stars and morality in Egypt. Women's Studies International Forum, 24(6), 711-725.

Starrett, G. (1995). The political economy of religious commodities in Cairo. American Anthropologist, 97 (1), 51-68.

Turner, B. S. (2008). Introduction: the price of piety. Contemporary Islam, 2(1), 1-6. 